\section{Easier said than done: moral decisions in medical uncertainty}

Milton D Heifetz, Buffalo, NY, Prometheus Books, 1992, 273 pages, $£ 18.50$

Discussions of complex medical issues are often clouded by tradition, dogma and gut reaction. In this book Milton D Heifetz describes a physician's perspective on the field of medical ethics.

In the first chapter the author builds a simple concept of ethics from an ideological basis of pure reason. In principle, this non-religious moral framework should have a broad appeal to people of all races and creeds. Four fundamental ethical precepts are proposed, which are adapted from Beauchamp and Childress's well known 'four principles'. These are, in order of priority: non-maleficence; freedom; the common good, and beneficence. The precepts seem in accord with human biological nature, and are broadly supported by religious and secular philosophy.

The next chapters consider various problems in the application of these concepts. An important distinction is made between the human right to seek and the right to have. The ethics of the changing doctor/patient relationship are discussed in some detail, as are the implications of the right of self-determination (an extension of freedom) from which so much ethical debate arises. The idea of mental competence is developed with particular relevance to the problem of the incompetent patient. The author points out that the widespread adoption of advance directives, or living wills, would reduce much of the anguish associated with these patients. There are valuable examples of advance directives included in the text.
The rest of the book concerns itself with the balanced application of the four principles in various common medical situations including: suicide; abortion; euthanasia; human experimentation, and triage and resource allocation. Throughout these chapters Dr Heifetz adopts an ethical position where self-determination is paramount. Thus, an individual's right to seek suicide, abortion or euthanasia is broadly supported. Counter-arguments concerning the 'sanctity of life' are given short shrift. The conclusions need not be taken as gospel, but the development of the ethical arguments in these examples is well worth reading.

While much of the language in the book is clear and direct, there are occasional irritating passages which have clumsy vocabulary and grammar. However, I found this book a concise and helpful distillation of what is an enormous religious and secular literature on the field of ethics. The re-working of the four fundamental ethical principles which Dr Heifetz proposes is perhaps the most valuable aspect of the book, and should help guide physicians through ethical problems with clearer minds and consciences.

\section{DR NICHOLAS J ALP, PhD} Wolfson College, Oxford.

\section{The philosophical and theological}

\section{foundations of ethics:}

an introduction to moral theory and its relation to religious belief

Peter Byrne, Basingstoke, Macmillan, New York, St Martin's Press, 1992, viii +168 pages, $£ 40$
It is unfortunate that the authors of the 1993 papal encyclical, Veritatis Splendor, could not have read this book before they wrote. They would have warmed to the preface, with its conclusion that the objectivity of moral truth and of religious truth stand or fall together. They would then have pursued a study of how moral judgements are made; and this is rather different from the way in which they appear to wish them to be made.

The book is not about medical ethics, although philosophers who elaborate theories for medical ethics should read it. The real moral agents, that is practitioners in medicine and those engaged with them on ethics committees in the shaping of decisions, will profit from the exposition of double effect in chapter three, and of how we make moral choices together in chapters six and eight. The book is written with the gravity and austerity proper to philosophical discourse and personal to its author. That he is no stranger to the discipline of medical ethics is evidenced by his creditable list of publications in this field.

Byrne's own rooted conviction is with Aristotle in seeing in rationality the characteristic basis of morality, that is of human excellence fulfilled in a community of rational, morally active, human beings. From this ground he engages with the theories of several moral philosophers, most of whom have been writing within the last twenty years. The first three chapters study the nature of morality a distinctive form of thought about conduct, not simply about acts - and its objectivity; the priority of conscience and shared moral knowledge over systems, moral rules and theories; training in the exercise of moral reflection and action within communities of trust; and the moral structure of action - a chapter in which Aquinas is expounded and his limitations uncovered. Here, too, the 
principles of double effect and of a proper casuistry are illustrated as a necessary means of escape from the crippling anti-moralities of rigorist and absolutist moral systems.

In the three central chapters Byrne argues with his peers about moral theories, the consequentialist, the deontological and the aretaic. Despite the advantages, clearly outlined, of consequentialism, it does not satisfy: both its assumed 'basic good' and its method of argument are criticized. A strict calculation of benefits may conflict with what conscience calls justice: there is a mode of wrongness to which utilitarianism, even in its refined forms, can be blind, irrespective of calculated utility or disutility. The primacy given to conscience in social relationships is asserted in the conclusion of the chapter.

Having rescued Kant from the absolutism blind to consequence mistakenly attributed to him, Byrne argues with neo-Kantian deontologists and new exponents of a social contract. The medical and social ethics of today are seriously distorted by the individualism which denies obligations to others unless we have freely chosen those obligations: the ideology is at variance with our knowledge of ourselves as aware of, and educated by, our relational ties and obligations. Such self-knowledge is essential to our concept of human dignity, and stands to challenge all moral theories.

It is not surprising, then, that Byrne's prose and moral reasoning are at their most relaxed in the chapter on aretaism, with its leading quotation from Aristotle: 'Only one who has acquired the virtues through action and experience can be practically wise'. Ethics is a practical discipline; its goal is knowledge of how to choose and act - a key maxim, surely, for practitioners in medical ethics. (Helen Oppenheimer's writing on 'moral beings' as 'choosing beings' may be recalled here, and her book The Hope of Happiness [SCM Press, 1993].) The aretaic stress on virtues, habits of choice, as the key to ethics does not exclude appeals to the deontologists' act-types and rules, or the consequentialists' results of action; it can accept and include them when morally relevant. Neither does the stress on the rational life as the characteristic basis of human excellence exclude the emotions and their proper expression in social living. In the examined life, rationality governs the capacity to enjoy. Because our distinctive human nature can only be fulfilled in community, the aretaic theory seeks for the closest possible integration between private good and public objective rights - another key to many of the tensions in medical ethics.

In the last two chapters Byrne returns to a dialogue about morality without and with religion. His aim is to go behind the adversarial conflicts between religion and the secularists on the autonomy of ethics. A review in this journal is not the place to analyse that argument. There are, however, some good things to be picked up by the way, because of Byrne's locating of morality in the widest conceptions of reality. The notion of eternal life, for instance, must embody an ideal of the completion and perfection of human striving for the best, a notion with little attraction for those careless of it here. An apt analogy elucidates why, without a blush, we constantly pass moral judgement on what scriptures, churches and other sources of 'revelation' tell us are God's laws, God's will: the laws of the state are authoritative, as distinct from powerful, only if there are, independent of them, some concepts of 'good' justice, security, freedom - to make those laws worthy of obedience; without this, mere enactment does not make courses of action right. The right is that which embodies respect for the good, which the divine will, as order-creating, lays down. Such perception is not denied to those without belief in God; they are moral beings because created members of a moral order. The autonomy of the moral agent is preserved.

Fortunately, we are not called upon to choose a moral theory on which to ground our judgements in medical ethics. 'Philosophy cannot produce a decision procedure for ethics.' In the Aristotelian tradition the aim of ethics is not right belief but right action. 'Excellence in it is excellence in the making of choices, not in the devising or discovery of theories or metaphysical systems.' Divergent starting points can be accepted because they lead to insight at the point where it matters.

The book is blemished only by bad proof-reading, a defect which publishers, when publishing was a house craft and pride, were at pains to avoid.

G R DUNSTAN Honorary Research Fellow, Department of Theology, University of Exeter.
In the case of children: paediatric ethics in a Canadian

\section{context}

Edited by Francoise Baylis and Cate McBurney, Toronto, Department of Bioethics, The Hospital for Sick $\stackrel{\mathbb{Q}}{\Omega}$ Children, Toronto, 1993, 164 pages $\$ 15$ (Canada), \$20 (international) o

This is a resource book for health care professionals working with childrege. It contains over 30 fictional fictionalised case reports coveriz్dg moral dilemmas across a range of different situations which will be .. f interest to all who work professionally with children. The intention is that these reports should form the basis for discussions on ethical aspects $\rightarrow f$ paediatric practice. Although the book is subtitled paediatric ethics in $\mathrm{Tl}^{\mathrm{a}}$ Canadian context it will be a usepil source for medical ethics teach ్ㅏㅇ worldwide.

The topics range through importaft areas such as consent, proxy decigionmaking, parents who disagree, Tin fulness, aggressive treatment end-of-life decisions, child abusêa resource allocation. One of the imp tant points to emerge from the cage selection is that ethical issues are ofll pervasive in providing health care children.

Many of the situations described in the reports are common, but none tie less often difficult to manage. Otherer reports deal with issues that are at frontiers of paediatric knowledge akg research, but which highlight important areas where there is no ethien consensus.

Each case report is clearly written and relatively brief. The repoys provide a basis for analysing the ethical issues, and will certaiz provoke thought and lively discussion. There are no answers in this book, but reading and discussing the case reports will promote understanding the relevant issues. Each report $\mathrm{CH}^{\mathrm{s}}$ followed by a series of carefully cos structed questions to provoke critical thinking in controversial areas. In torms way the difficulties in making 'rig $\mathbb{R}_{\text {' }}$ ' decisions in complex real life situations are clearly brought out. A selegtion of relevant references for further reading is given at the end of each case report so that learners will be able 90 broaden their understanding of ethical issues raised in discussion. 